\title{
Comparing the Asthma Control and Anti-inflammatory Effects of Different Fixed Combinations of Inhaled Corticosteroids Plus Long-acting Beta 2 Agonist; A Randomized Clinical Trial
} \begin{abstract}
University, Zagazig, Egypt
Edited by: Ksenija Bogoeva-Kostovsk Citation: Sileem AE, Amin A, Elnahas H, Gouda AM. Effects of Different Fixed Combinations of Inhale Corticosteroids Plus Long-acting Beta 2 Agonist: $A$ Corticosteroids Plus Long-acting Beta 2 Agonist; $A$ Sci. 2021 Aug 21; 9(B):771-778. https://doi.org/10.3889/

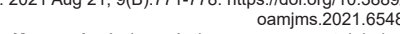
Keywords: Asthma; Asthma management; Inhale corticosteroids; Bronchodilators "Correspondence: Ahmed M. Gouda, Department of Pharmacy Practice, Faculty of Pharmacy, Zagazig University, Zagazig, Egypt. E-mail: amgoda@pharmacy.zu.edu.eg Received: 31-May-202 Accepted: 11-Aug-2021 Copyright: ๑ 2021 Ashraf Elsayed Sileem, Ahmed Al Hanan Elnahas, Ahmed M. Gouda Funding: This research did not receive any financia Competing Interests: The authors have declared that no competing interests exis Open Access: This is an open-access article distributed under the terms of the Creative Commons AttributionNonCommercial 4.0 International License (CC BY-NC 4.0)
\end{abstract}

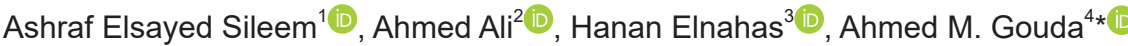

${ }^{1}$ Department of Chest Diseases, Faculty of Medicine, Zagazig University, Zagazig, Egypt; ${ }^{2}$ Department of Clinical Pharmacy, Faculty of Pharmacy, Kafr El-sheikh University, Kafr el-Sheikh, Egypt; ${ }^{3}$ Department of Pharmaceutical and Industrial Pharmacy, Faculty of Pharmacy, Zagazig University, Zagazig, Egypt; ${ }^{4}$ Department of Pharmacy Practice, Faculty of Pharmacy, Zagazig

\begin{abstract}
BACKGROUND: Asthma is the most common chronic inflammatory disease of the pulmonary system. The prevalence of asthma is growing enormously worldwide posing a significant health and economic burden. Asthma treatment guidelines recommend a combination of inhaled corticosteroid (ICS) and long-acting beta 2 agonist (LABA). However, there is little guidance for clinicians on selecting a specific ICS/LABA combination.

AIM: The aim of the study is to compare the effectiveness of three fixed dose ICS/LABA combination therapies, i.e. fluticasone/salmeterol, fluticasone/formoterol, and budesonide/formoterol for the management of moderate-tosevere asthma.

DESIGN: This was a prospective interventional, three-armed, parallel group, open label, and randomized clinical trial METHODS: Adult asthmatic patients of both genders $(n=135)$ were randomly allocated to the three ICS/LABA treatment groups: fluticasone/salmeterol-treated group $(n=45)$, fluticasone/formoterol-treated group $(n=45)$ and budesonide/formoterol-treated group $(n=45)$. All groups were treated for 3 months. The main outcome parameters included lung function (forced expiratory volume in $1 \mathrm{~s}$ [FEV1], FEV1\%, FEV1/forced vital capacity [FVC]), inflammatory state (high sensitivity C-reactive protein [hs-CRP], eosinophilic cationic protein [ECP]) and asthma control test $(\mathrm{ACT})$.

RESULTS: After 3 months of treatment, fluticasone/formoterol significantly increased FEV1 compared to fluticasone salmeterol $(p<0.01)$ and FEV1\% compared to budesonide/formoterol $(p<0.01)$. Both fluticasone-containing combinations significantly increased FEV1/FVC $(p<0.001, p<0.001)$, decreased serum hs-CRP $(p<0.01, p<$ $0.001)$, and serum ECP $(p<0.05, p<0.001)$ and improved ACT $(p<0.05, p<0.01)$ compared to budesonide. Fluticasone/formoterol significantly reduced ECP in comparison to fluticasone/salmeterol $(p<0.05)$.

CONCLUSION: Our study showed a superiority for fluticasone-containing combinations over budesonide for the treatment of moderate to severe asthma. Within the former combinations, fluticasone/formoterol was better than fluticasone/salmeterol.
\end{abstract}

\section{Introduction}

Asthma is a chronic heterogeneous disease characterized by chronic airway hyperresponsiveness and inflammation [1]. If uncontrolled, asthma can severely limit the patient's regular daily activity [2]. The key long-term goals for asthma management include achieving proper symptom control, maintaining normal lung function, and minimizing flare-ups and mortality [3].

Inhaled corticosteroids (ICS) are the most effective anti-inflammatory medications for long-term asthma management that reduce airway inflammation and hyperresponsiveness, asthma-related mortality, and improve quality of life [4], [5]. However, patients show variable responsiveness to ICS and some individuals may require higher ICS doses to gain full benefit from the treatment. Long-term treatment with high doses of ICS is associated with systemic side effects and therefore, combining normal-dose ICS with another class of controller is preferable to increasing the ICS dose [6].

Current guidelines recommend the use of ICS, for example., fluticasone and budesonide, in combination with long-acting beta 2 agonist (LABA),for example., formoterol and salmeterol, for patients with moderate-to-severe asthma [7]. The use of ICS/ LABA combinations has resulted in extraordinary improvements in asthma outcomes compared with increasing the dose of ICS [8]. Several fixed-dose ICS/ LABA combinations are available; however, there is little guidance for clinicians on selecting a specific ICS/ LABA combination [9].

Here, we designed a randomized clinical study to compare the effect of three available fixed-dose 
ICS/LABA combinations, i.e. fluticasone/salmeterol, fluticasone/formoterol, and budesonide/formoterol on the management of patients with moderate to severe asthma. The main outcome parameters that were investigated include lung function, systemic and airway inflammation, and asthma control.

\section{Materials and Methods}

\section{Sample size}

Assuming that the percent of enhancement in FEV1 following first dose of fluticasone/salmeterol versus budesonide/formoterol was ( $58 \%$ vs. $31 \%$ ) so the sample size is 135 , using open epi, Confidence interval $95 \%$, power of the test is $80 \%$

\section{Study subjects and ethical approval}

Patients with moderate-to-severe asthma aged $\geq 18$ years were recruited in this prospective, interventional study conducted at Zagazig University Hospital, a large tertiary hospital in Egypt. The study has been approved by the Institutional Research Board of Zagazig Faculty of Medicine under the code: 5246/1812-2019. Written informed consent was obtained from each patient.

\section{Inclusion criteria}

Asthma history that bronchodilator reversibility testing reported (about 12\% enhancement in FEV1 and about $200 \mathrm{ml}$ enhancement after four puffs, $90 \mu \mathrm{g}$ each, of salbutamol).

\section{Exclusion criteria}

Individuals younger than 18 years, patients with respiratory tract infection within the last 3 months before admission and hepatic, kidney, cardiovascular diseases, diabetes mellitus, cancer, systemic inflammatory disorders, and any patients with signs and symptoms of recent exacerbation of asthma during the period of study were excluded.

\section{Study design}

The study was a randomized, open-label, parallel-group, monocentre. After an initial screening visit, patients were randomized to one of three treatment groups according to the global Initiative for asthma guidelines (i.e. low dose for step 3 , medium-dose for step 4 or high dose for step 5): Group A, fluticasone/ salmeterol ( $n=45)$, group $B$, fluticasone/formoterol
( $n=45)$ and Group C, budesonide/formoterol $(n=45)$. The study flow diagram is shown in (Figure 1).

All patients underwent a thorough evaluation of symptoms, clinical examination, and review including full blood count (including eosinophilic circulating [CE] count), chest X-ray (posteroanterior view), serum total immunoglobulin $\mathrm{E}$ ( $\lg E$ ) (at baseline), lung function test (at baseline and after 3 months), serum high sensitivity C-reactive protein (hs-CRP) (at baseline and after 3 months), serum eosinophilic cationic protein (ECP) (at baseline and after 3 months), and asthma control test (ACT) (at baseline and every 4 weeks for 3 months).

\section{Lung function test}

Spirometric lung function test was performed using Sensor Medicus 2450 computerized pulmonary function apparatus with reversibility tests after salbutamol inhalation $(4 \times 100 \mathrm{mcg})$ provided by metered-dose inhaler using a spacer system. It would test forced vital capacity (FVC) and forced expiratory volume in $1 \mathrm{~s}$ (FEV1). The best value of three maneuvers was calculated as a percent of the presumed value and as absolute value.

\section{Blood collection}

Peripheral venous blood samples were collected from all patients after overnight fasting. The blood samples were centrifuged at $1300 \mathrm{~g}$ for $10 \mathrm{~min}$ at $4^{\circ} \mathrm{C}$, and the serum samples were kept frozen at $-70^{\circ} \mathrm{C}$ until analysis.

\section{Serum hs-CRP}

Serum hs-CRP levels were measured using the Human hs-CRP ELISA Kit (Shanghai Sunred Biological Technology Co., Ltd., Cat no. 201-12-1806).

\section{Serum ECP}

Serum ECP levels will be measured using Human ECP ELISA Kit. (Shanghai Sunred Biological Technology Co., Ltd., Cat no. 201-12-1392).

\section{Serum total IgE}

Serum total IgE levels were measured by ImmunoSpec IgE Quantitative Enzyme Immunoassay (Immunospec Corporation, Ref no. E29-006). Measurement of Serum total IgE levels was used as a diagnostic tool to differ between atopic and non-atopic asthmatic patients so it was measured at baseline only. 


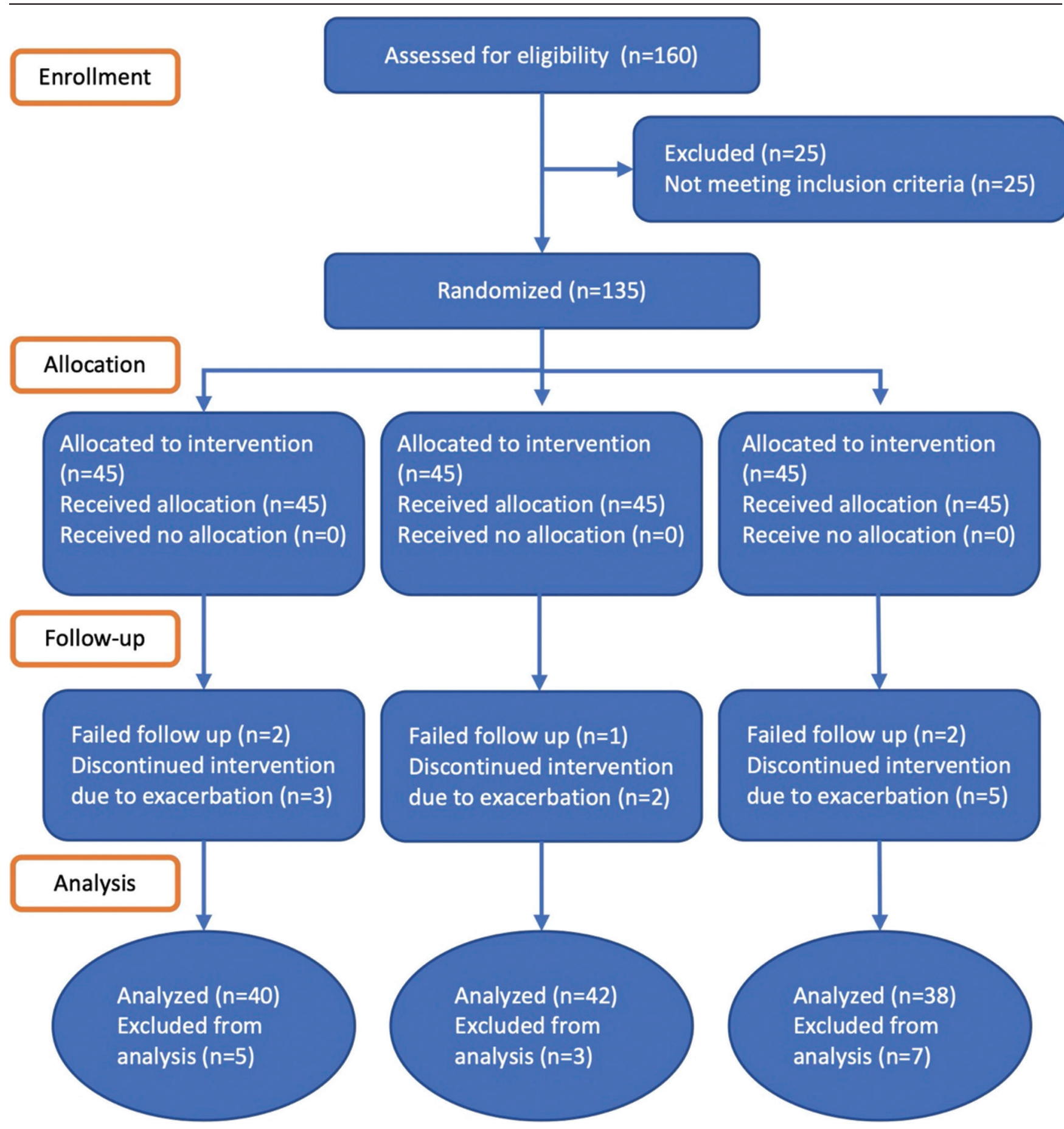

Figure 1: The study flow diagram

\section{ACT}

The ACT is a standardized self-administered questionnaire that contains five questions relevant to the last 4 weeks: episodes of breathless, nocturnal waking, regular activity restrictions, need for rescue therapy, and patients self-rating of asthma management [10]. Each question contains five modalities of answer with a score ranging from 1 to 5 by increasing asthma control level, so the global arithmetic score ranges from 5 (poorest asthma control) to 25 (optimal asthma control). Scores from 20 to 25 are classified as well-controlled asthma; 16 to 19 as not well-controlled; and 5 to 15 as very poorly managed asthma.

\section{Statistical analysis}

All data are expressed as the mean \pm SD for numeric variables and as the number (percentage) for categorical variables. Comparisons were determined by paired t-test, one-way ANOVA, or repeated measures two-way ANOVA for continuous variables as appropriate followed by Tukey's or Sidak's multiple comparisons tests (post-hoc tests). Comparisons of categorical variables were assessed by a $\chi 2$ (Chi-square) or McNemar-Bowker test as appropriate. A $p<0.05$ was considered to indicate statistical significance after multiple testing corrections. Data were analysed using Graph Pad Prism version 8.2 and SPSS version 26. 


\section{Results}

\section{Demographic data of all asthmatic patients at baseline and Patient characteristics}

About 160 asthmatic patients were recruited from the outpatient department at Zagazig University Hospitals. Twenty-five patients were excluded as they did not meet the inclusion criteria. The remaining 135 patients were randomly allocated to the treatment groups. During the study, 15 patients were excluded due to exacerbation $(n=10)$ and loss of follow-up $(n=$ 5 ). Therefore, the final number of patients included in

Table 1: Demography and baseline characteristic

\begin{tabular}{ll}
\hline & Mean \pm SD or $\mathrm{n}(\%)$ \\
\hline Age (years) & $36 \pm 11$ \\
Male, $\mathrm{n}(\%)$ & $67(56 \%)$ \\
Female, $\mathrm{n}(\%)$ & $53(44 \%)$ \\
Atopic asthmatic patients, $\mathrm{n}(\%)$ & $42(35 \%)$ \\
Non atopic asthmatic patients, $\mathrm{n}(\%)$ & $78(65 \%)$ \\
Smokers, $\mathrm{n}(\%)$ & $36(30 \%)$ \\
Non-smokers, $\mathrm{n}(\%)$ & $45(38 \%)$ \\
Former smokers, $\mathrm{n}(\%)$ & $39(33 \%)$ \\
Duration of asthma (years) & $13.5 \pm 13.7$ \\
Comorbidities, $\mathrm{n}(\%)$ & $77(64 \%)$ \\
Hypertension, $\mathrm{n}(\%)$ & $9(12 \%)$ \\
Obesity, $\mathrm{n}(\%)$ & $13(17 \%)$ \\
GERD, $\mathrm{n}(\%)$ & $10(13 \%)$ \\
Allergic comorbidities, $\mathrm{n}(\%)$ & $45(58 \%)$ \\
FEV1\% & $2.4 \pm 0.5$ \\
ACT & $16 \pm 4$ \\
hsCRP (mg/l) & $2.8 \pm 1.0$ \\
ECP (ng/l) & $22.8 \pm 6.9$ \\
\hline Values are represented as mean \pm SD or $\mathrm{n}(\%)$. ACT: Asthma control test; ECP: Eosinophilic cationic \\
protein; FEV1: Forced expiratory volume; GERD: Gastro esophageal reflux disease; hsCRP: high sensitivity \\
C-reactive protein.
\end{tabular}

the analysis was 120 (40 in group A, 42 in B, and 38 in C). Demographic data, smoking history, comorbidities, lung function, and other biomarkers at baseline are summarized in (Table 1). Patients' characteristics, i.e. age, gender, comorbidities, smoking history, and duration of asthma were similar between the three groups (Table 2).

Table 2: Patients' characteristics in the different treatment groups

\begin{tabular}{lllll}
\hline & $\begin{array}{l}\text { Group A } \\
(\mathrm{n}=40)\end{array}$ & $\begin{array}{l}\text { Group B } \\
(\mathrm{n}=42)\end{array}$ & $\begin{array}{l}\text { Group C } \\
(\mathrm{n}=38)\end{array}$ & p-value \\
\hline Age (years) & $37 \pm 11$ & $37 \pm 12$ & $34 \pm 10$ & 0.66 \\
Male, $\mathrm{n}(\%)$ & $17(43 \%)$ & $28(66 \%)$ & $22(58 \%)$ & 0.08 \\
Female, $\mathrm{n}(\%)$ & $23(57 \%)$ & $14(34 \%)$ & $16(42 \%)$ & 0.08 \\
Asthma onset (years) & $24(60 \%)$ & $28(66 \%)$ & $23(60 \%)$ & 0.79 \\
Hypertension, $\mathrm{n}(\%)$ & $4(10 \%)$ & $4(10 \%)$ & $1(3 \%)$ & 0.39 \\
Allergic rhinitis, $\mathrm{n}(\%)$ & $6(15 \%)$ & $3(7 \%)$ & $6(16 \%)$ & 0.43 \\
Atopic dermatitis, $\mathrm{n}(\%)$ & $5(13 \%)$ & $3(7 \%)$ & $3(8 \%)$ & 0.66 \\
Allergic conjunctivitis, $\mathrm{n}(\%)$ & $3(8 \%)$ & $3(7 \%)$ & $3(8 \%)$ & 0.99 \\
Allergic contact dermatitis, $\mathrm{n}(\%)$ & $3(8 \%)$ & $4(10 \%)$ & $3(8 \%)$ & 0.94 \\
Obesity, $\mathrm{n}(\%)$ & $5(13 \%)$ & $5(12 \%)$ & $3(8 \%)$ & 0.78 \\
GERD, $\mathrm{n}(\%)$ & $2(5 \%)$ & $4(10 \%)$ & $4(11 \%)$ & 0.64 \\
Smokers, $\mathrm{n}(\%)$ & $12(30 \%)$ & $12(29 \%)$ & $12(32 \%)$ & 0.96 \\
Duration of asthma (years) & $11 \pm 10$ & $14 \pm 15$ & $15 \pm 15$ & 0.43 \\
\hline Values are represented as mean \pm SD or $\mathrm{n}(\%)$. Comparisons of categorical variables were assessed by \\
a x2 (Chi-square), Comparisons of continuous variables were determined by one-way ANOVA followed by \\
Tukey's multiple comparison tests (post-hoc tests). Duration of asthma in years. GERD: Gastroesophageal \\
reflux disease
\end{tabular}

\section{Serum total IgE measured at baseline}

Total IgE is a surrogate marker of eosinophilic inflammation in patients with allergic asthma. ImmunoSpec IgE quantitative test was used to differentiate between atopic and non-atopic asthmatic patients. Indeed, there was no significant statistical difference between the three groups in total serum $\lg E$ values (Figure 2).

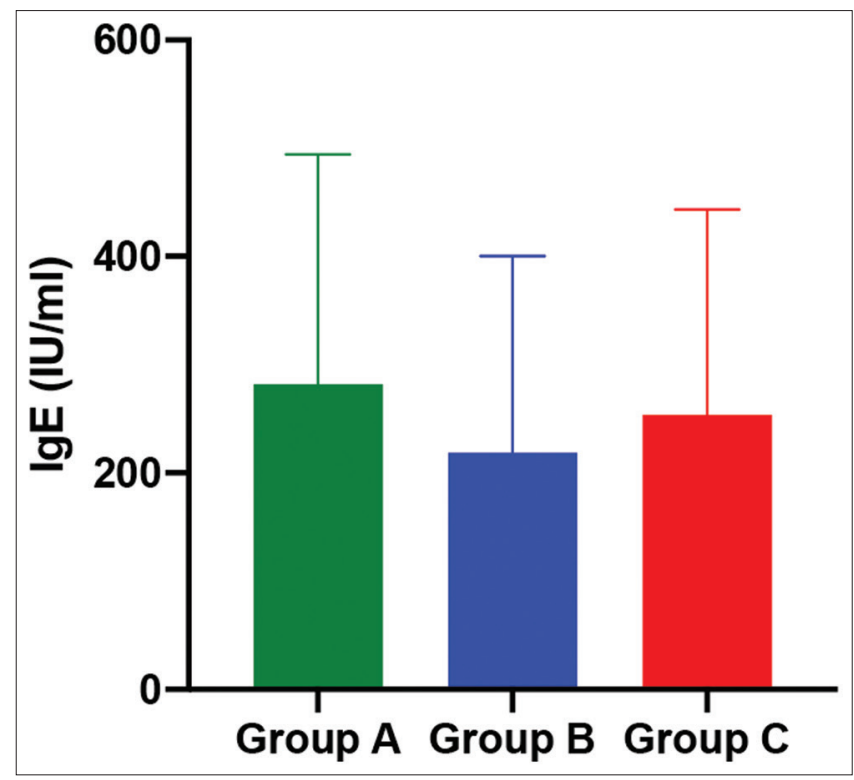

Figure 2: Serum total IgE in asthmatic patients at baseline

\section{Lung function test at baseline and after treatment for 3 months}

Spirometry lung function test showed a significant increase in FEV1, FEV1\%, and FEV1/ FVC ratio in all groups after treatment compared to baseline $(p<0.001)$. The increase in FEV1 and FEV1\% by fluticasone/formoterol (group B) was significantly higher than fluticasone/salmeterol (group A) (Figure 3a) and budesonide/formoterol (group C) (Figure 3b), respectively. The increases in FEV1/FVC ratio in fluticasone/formoterol and fluticasone/salmeterol groups were significantly higher than budesonide/ formoterol group (Figure 3c).

\section{after treatment \\ Inflammatory biomarkers at baseline and}

To compare systemic inflammation status between the treatment groups, serum hs-CRP levels were measured in all patients at baseline and after treatment for 3 months. All patients of the 3 groups had high serum hs-CRP levels at baseline which were significantly decreased after treatment for 3 months $(p<0.001)$. However, the decreases in serum hs-CRP levels in group $A$ and group $B$ were significantly different from group $\mathrm{C}$ after 3 months of treatment (Figure 4a).

To compare eosinophils activation/airway inflammation between the treatment groups, serum ECP levels were measured in all patients at baseline and after treatment for 3 months. All patients of the 3 groups had high serum ECP levels at baseline which were significantly decreased after treatment for 3 months $(p<0.001)$. However, the decreases 


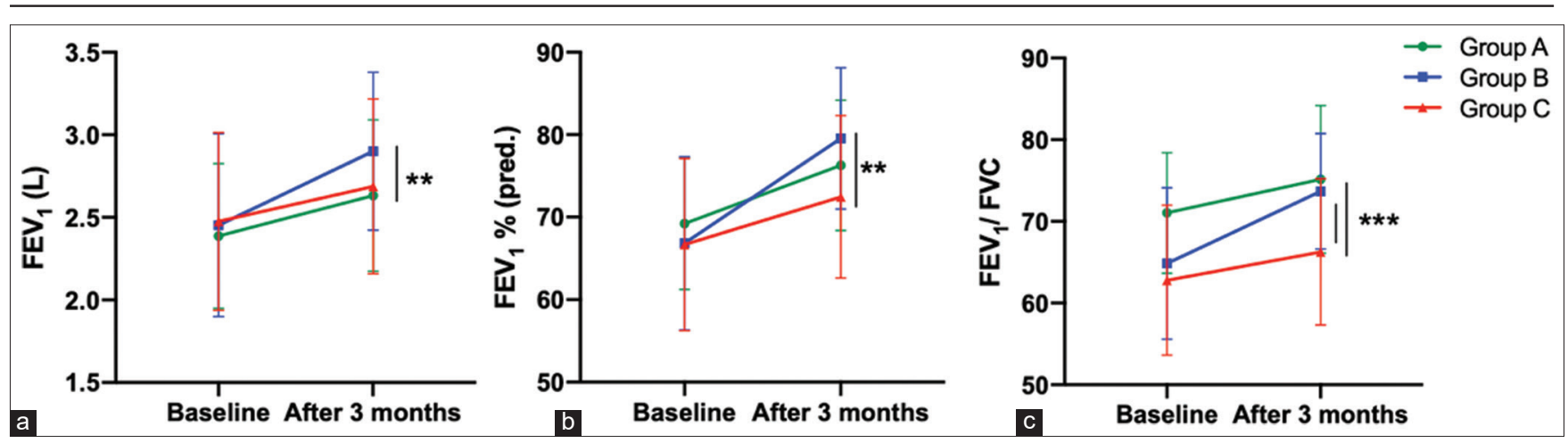

Figure 3: a. FEV1, b. FEV1\% predicted, c. FEV1/FVC in asthmatic patients at baseline and after treatment for 3 months. ${ }^{* *} p<0.01,{ }^{* * *}$ $p<0.001$.

in serum ECP levels in Group A and Group B were significantly different from Group $C$ after 3 months of treatment. Interestingly, serum ECP levels were significantly reduced in Group B compared to Group A (Figure 4b).
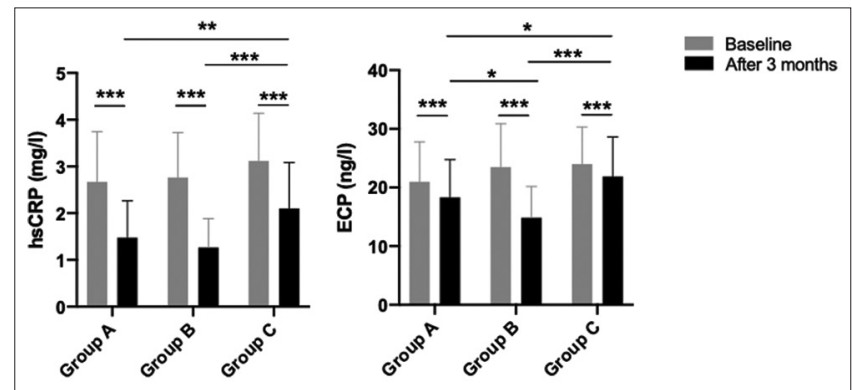

a C-reactive protein (hs-CRP), b. serum eosinophilic cationic protein $(E C P)$ in asthmatic patients at baseline and after treatment for 3 months. ${ }^{*} p<0.05,{ }^{* *} p<0.01,{ }^{* * *} p<0.001$

\section{ACT}

To determine and compare the effects of treatments on the control of asthma, ACT was performed at baseline and every month for 3 months after treatment. At baseline, all patients of the three groups had low ACT scores that were significantly improved at all the subsequent time points $(p<0.001)$. After 3 months of treatment, ACT score was significantly higher in Group A and Group B compared to Group C (Figure 5).

Further analysis of ACT score showed that there were $40 \%, 69 \%$, and $37 \%$ well-controlled cases in groups $A, B$, and $C$, respectively, after 3 months of treatment. In Group A, there was significant change in asthma control from partially controlled to wellcontrolled. In Group B, there was significant change in asthma control from poorly controlled to partially controlled and from partially controlled to wellcontrolled. Similarly, in Group C, there was significant change in asthma control from poorly controlled to partially controlled and from partially controlled to wellcontrolled (Table 3).

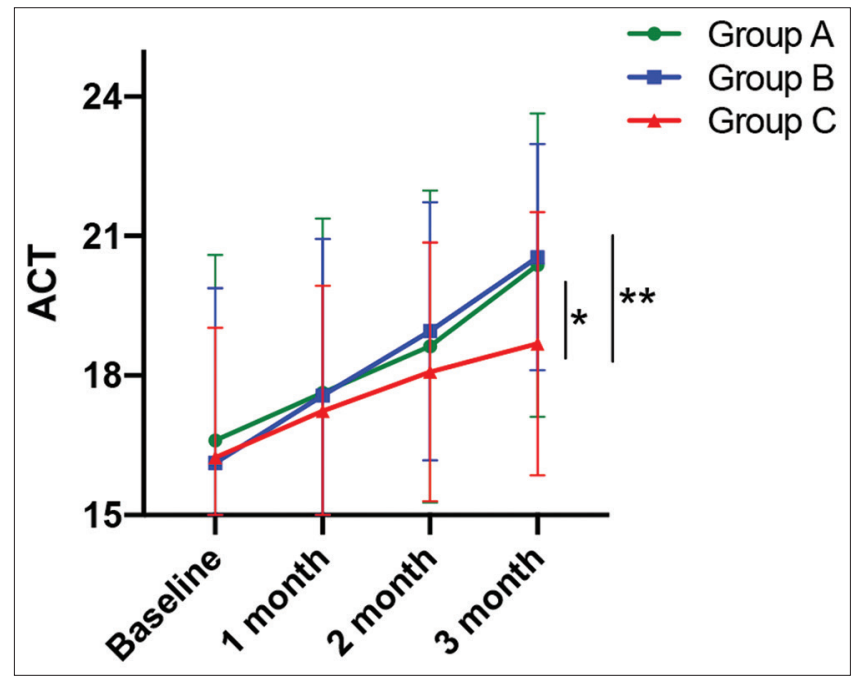

Figure 5: Asthma control test (ACT) score in asthmatic patients at baseline and after treatment for 3 months. ${ }^{*} p<0.05,{ }^{* *} p<0.01$

\section{Asthma severity}

In this study, patients with moderate and severe asthma were recruited and randomly assigned Table 3: The change in asthma control (ACT)

\begin{tabular}{|c|c|c|c|c|c|c|}
\hline Group & ACT & Baseline & $\begin{array}{l}\text { After } 3 \\
\text { months }\end{array}$ & $p$-value & Post-hoc & $p$-value \\
\hline \multirow[t]{3}{*}{ A } & $\begin{array}{l}\text { Poorly } \\
\text { controlled }\end{array}$ & 6(15\%) & $5(12.5 \%)$ & 0.0041 & Poorly $\Leftrightarrow$ Partially & ns \\
\hline & $\begin{array}{l}\text { Partially } \\
\text { controlled }\end{array}$ & $\begin{array}{l}28 \\
(70 \%)\end{array}$ & $19(47.5 \%)$ & & Poorly $\Leftrightarrow$ Well & ns \\
\hline & $\begin{array}{l}\text { Well } \\
\text { controlled }\end{array}$ & $6(15 \%)$ & $16(40 \%)$ & & Partially $\Leftrightarrow$ Well & 0.002 \\
\hline \multirow[t]{3}{*}{ B } & $\begin{array}{l}\text { Poorly } \\
\text { controlled }\end{array}$ & $\begin{array}{l}12 \\
(28.5 \%)\end{array}$ & $0(0 \%)$ & 0.0000005 & Poorly $\Leftrightarrow$ Partially & 0.004 \\
\hline & $\begin{array}{l}\text { Partially } \\
\text { controlled }\end{array}$ & $\begin{array}{l}23 \\
(54.8 \%)\end{array}$ & $13(31 \%)$ & & Poorly $\Leftrightarrow$ Well & ns \\
\hline & $\begin{array}{l}\text { Well } \\
\text { controlled }\end{array}$ & $\begin{array}{l}7 \\
(16.7 \%)\end{array}$ & $29(69 \%)$ & & Partially $\Leftrightarrow$ Well & 0.000002 \\
\hline \multirow[t]{3}{*}{ C } & $\begin{array}{l}\text { Poorly } \\
\text { controlled }\end{array}$ & $\begin{array}{l}14 \\
(36.8 \%)\end{array}$ & $6(15.8 \%)$ & 0.0004 & Poorly $\Leftrightarrow$ Partially & 0.016 \\
\hline & $\begin{array}{l}\text { Partially } \\
\text { controlled }\end{array}$ & $\begin{array}{l}21 \\
(55.3 \%)\end{array}$ & $18(47.4 \%)$ & & Poorly $\Leftrightarrow$ Well & ns \\
\hline & $\begin{array}{l}\text { Well } \\
\text { controlled }\end{array}$ & $3(7.9 \%)$ & $14(36.8 \%)$ & & Partially $\Leftrightarrow$ Well & 0.002 \\
\hline
\end{tabular}


to the different treatment groups. At baseline, there was no significant difference in asthma severity between the 3 groups. After 3 months of treatment, there was significant improvement in all groups compared to baseline, however, group $B$ had significant improvement compared to group A and group C. Number and percentage of patients with mild, moderate and severe asthma at baseline and after treatment are represented in (Figure 6).

\section{Discussion}

In this study, we compared the efficacy of three common ICS/LABA combinations i.e. fluticasone/ salmeterol, fluticasone/formoterol and budesonide/ formoterol, in controlling asthmatic patients after 3 months of treatment. All ICS/LABA tested improved lung function, asthma control, and reduced systemic and airway inflammations. Fluticasone-containing combinations, in particular fluticasone/formoterol, were more effective than budesonide-containing combination.

Previous studies showed that ICS/LABA combinations used in our study have greatly improved lung functions in asthmatics compared to placebo after 12-week treatment [11]. Fluticasone/formoterol has been shown to be effective as fluticasone/salmeterol, yet has a more rapid onset of action, reflecting the faster bronchodilator effects of formoterol compared with those of salmeterol [12]. In contrast to our findings that fluticasone-containing combinations are superior to budesonide-containing combination, others showed that budesonide/formoterol is more effective than fluticasone/salmeterol in treatment of moderate to severe asthma [13]. This conflict might be indicative of the different treatment responsiveness in different populations.

Inflammatory markers as hs-CRP and ECP are increased in asthmatics compared to healthy individuals [14], [15], [16]. hs-CRP is an indicator of chronic, low grade inflammation in many conditions including asthma [17]. High serum ECP level may be a predictor for asthma exacerbation and treatment effect, thus it may be a useful control parameter in asthma [18]. ICS including fluticasone and budesonide have been shown to be effective in reducing serum levels of hs-CRP [19] and ECP [20] asthma. In line with our findings, previously serum hs-CRP and ECP were reduced in asthmatic patients who were followed up after 2 months of therapy [16]. To our knowledge, our study is the first to compare the effectiveness of different ICS/LABA combinations on serum levels of hs-CRP and ECP and thus further studies are needed.

The ACT is a numerical score, developed by asthma experts, to assess the control of asthma. It is a useful measure to help determine the level of treatment required [21]. In a study that contained 5789 asthmatic patients from Poland, treated in clinically appropriate doses using one of three ICS/LABA inhalers fluticasone/ salmeterol, beclomethasone/formoterol or budesonide/ formoterol the investigators reported that control increased from $22.6 \%$ to $66.4 \%$ after 6 months of follow up, While our study showed an overall increase of asthma control from $13.3 \%$ to $49.2 \%$ [22]. This difference between our study and this study could be attributed to different study population as we studied less controlled subjects and they followed their subjects for more prolonged period (6 months vs. 3 months in our study). Another, large real-life study that included 1563 asthmatic patients receiving fluticasone/formoterol treatment and were observed over 1 year, showed a

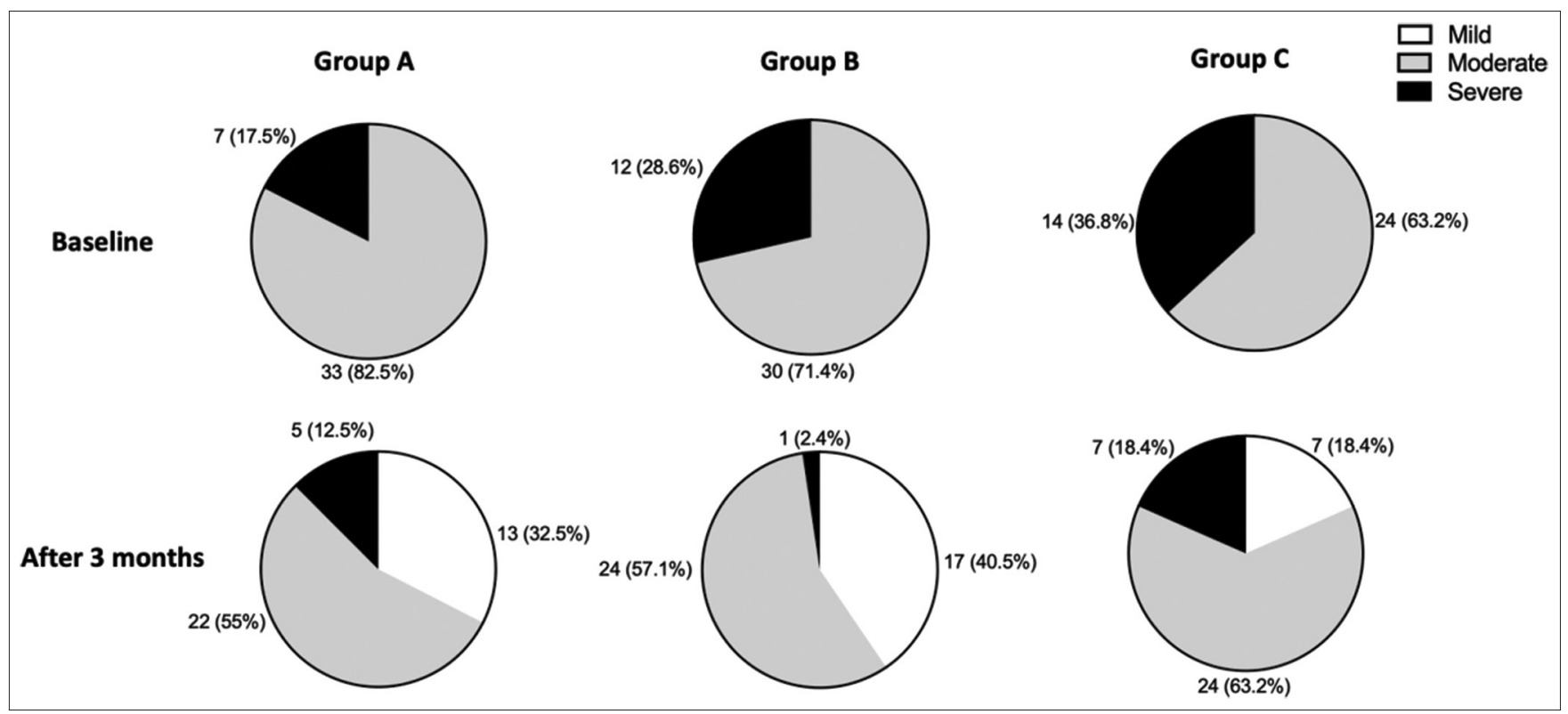

Figure 6: Asthma severity in asthmatic patients at baseline and after treatment for 3 months. Data are represented as $n$ (\%) 
comparable increase in their increase in the number of patients with asthma control from $30.9 \%$ at baseline to $62.4 \%$ at the end of the study versus $16.7 \%$ to $69 \%$ in our fluticasone/formoterol group. Moreover, the percentage of patients whose disease was 'somewhat controlled' (total score 16-19) decreased slightly from baseline to end of study (25.9-21.0\%) versus (54.8-31\%) in our study; the percentage of patients whose disease was poorly controlled (total score <15) decreased substantially (43.1-16.7\%) versus $(28.5-0 \%)$ in our study [23].

The current work has some limitations. First, relatively low number of study population. Second, being a mono center study. Third, the absence of a control arm to compare the effect of the studied medications to placebo or other treatments. Fourth, data on prior medications was not reported for our included patients. Finally, as randomized trial, our study needs to be complemented with real- life observational studies.

\section{Conclusion}

The effectiveness of three fixed-dose ICS/ LABA combinations i.e. fluticasone/salmeterol, fluticasone/formoterol and budesonide/formoterol for the management of moderate to severe asthma was studied. Overall, based on the findings of the current study, all ICS/LABA combinations tested were effective in improving lung functions, reducing inflammations and controllingasthma. Fluticasone-containing combinations have the upper hand in asthma related inflammation and control. However, fluticasone/formoterol was better than fluticasone/salmeterol and budesonide/formoterol. Therefore, fluticasone/formoterol is suggested as a first-line ICS/LABA combination therapy to be used in patients with moderate to severe asthma.

\section{Acknowledgements} discussions.

We thank Mahmoud Elbatreek for helpful

\section{References}

1. Holgate ST. Asthma: Clinical aspects and mucosal immunology In: Mucosal Immunology. Amsterdam, Netherlands: Elsevier; 2015. p. 1833-56.

2. Aalbers R, Vogelmeier C, Kuna P. Achieving asthma control with ICS/LABA: A review of strategies for asthma management and prevention. Respir Med. 2016;111:1-7. https://doi.org/10.1016/j. rmed.2015.11.002

PMid:26614594

3. Beasley R, Braithwaite I, Semprini A, Kearns C, Weatherall M, Pavord ID. Optimal asthma control: Time for a new target. Am J Respir Crit Care Med. 2020;201(12):1480-7. https://doi. org/10.1164/rccm.201910-1934ci

PMid:31905013

4. Juniper EF, Kline PA, Vanzieleghem MA, Ramsdale EH, O'Byrne PM, Hargreave FE. Effect of long-term treatment with an inhaled corticosteroid (budesonide) on airway hyperresponsiveness and clinical asthma in nonsteroiddependent asthmatics. Am Rev Respir Dis. 1990;142(4):832-6. https://doi.org/10.1164/ajrccm/142.4.832

PMid:2221590

5. Idzko M, Hartl S, Lamprecht B, Reisinger M, Löffler-Ragg J, Rauter M, et al. New insights from GINA 2019/2020-focus on early anti-inflammatory therapy. Wien Klin Wochenschr. 2021;133:1-6. https://doi.org/10.1007/s00508-021-01830-1 PMid:33770268

6. Acosta WR. Study Guide for Pharmacology for Health Professionals. United States: Jones and Bartlett Publishers; 2020.

7. Tashkin DP, Ohar JA, Koltun A, Allan R, Ward JK. The role of ICS/LABA fixed-dose combinations in the treatment of asthma and COPD: Bioequivalence of a generic fluticasone propionatesalmeterol device. Pulm Med. 2021;2021:8881895. https://doi. org/10.1155/2021/8881895

8. Calzetta L, Ritondo BL, de Marco P, Cazzola M, Rogliani P. Evaluating triple ICS/LABA/LAMA therapies for COPD patients: A network meta-analysis of ETHOS, KRONOS, IMPACT, and TRILOGY studies. Expert Rev Respir Med. 2021;15(1):143-52. https://doi.org/10.1080/17476348.2020.1816830

PMid:32856967

9. Noibi S, Mohy A, Gouhar R, Shaker F, Lukic T, Al-Jahdali H. Asthma control factors in the gulf cooperation council (GCC) countries and the effectiveness of ICS/LABA fixed dose combinations: A dual rapid literature review. BMC Public Health. 2020;20(1):1-16. https://doi.org/10.1186/s12889-020-09259-3 PMid:32770967

10. Koolen B, Pijnenburg $M$, Brackel $H$, Landstra A, Van den Berg N, Merkus $\mathrm{P}$, et al. Comparing global initiative for asthma (GINA) criteria with the childhood asthma control test (C-ACT) and asthma control test (ACT). Eur Respir J. 2011;38(3):561-6. https://doi.org/10.1183/09031936.00173710 PMid:21406508

11. Emeryk A, Klink R, Mclver T, Dalvi P. A 12-week open-label, randomized, controlled trial and 24-week extension to assess the efficacy and safety of fluticasone propionate/formoterol in children with asthma. Ther Adv Respir Dis. 2016;10(4):324-37. https://doi.org/10.1177/1753465816646320

PMid:27185164

12. Bodzenta-Lukaszyk A, Buhl R, Balint B, Lomax M, Spooner K, Dissanayake $\mathrm{S}$. Fluticasone/formoterol combination therapy versus budesonide/formoterol for the treatment of asthma: A randomized, controlled, non-inferiority trial of efficacy and safety. J Asthma. 2012;49(10):1060-70. https://doi.org/10.3109/ 02770903.2012.719253

PMid:23102189

13. Chang TY, Chien JY, Wu CH, Dong YH, Lin FJ. Comparative safety and effectiveness of inhaled corticosteroid and longacting $\beta 2$-agonist combinations in patients with COPD. Chest. 2020;157(5):1117-29. https://doi.org/10.1016/j. chest.2019.12.006

PMid:31887282 
14. Takemura $\mathrm{M}$, Matsumoto $\mathrm{H}$, Niimi $\mathrm{A}$, Ueda $\mathrm{T}$, Matsuoka $\mathrm{H}$, Yamaguchi $\mathrm{M}$, et al. High sensitivity $\mathrm{C}$-reactive protein in asthma. Eur Respir J. 2006;27(5):908-12. https://doi.org/10.11 83/09031936.06.00114405

PMid:16707391

15. Stoleski S, Minov J, Karadzinska-Bislimovska J, Mijakoski D, Atanasovska A. Eosinophil cationic protein concentrations among crop and dairy farmers with asthma. Open Access Maced J Med Sci. 2018;6(3):456. https://doi.org/10.3889/ oamjms.2018.113

PMid:29610600

16. Sileem AE, Embarak S, Meleha MS. Serum eosinophilic cationic protein and high sensitive C-reactive protein as alternative parameters for differentiation of severity stages and monitoring control in bronchial asthma patients. Egypt J Chest Dis Tuberc. 2014;63(4):765-70. https://doi.org/10.1016/j.ejcdt.2014.07.001

17. Shimoda $T$, Obase $Y$, Kishikawa R, Iwanaga T. Serum highsensitivity $\mathrm{C}$-reactive protein can be an airway inflammation predictor in bronchial asthma. Allergy Asthma Proc. 2015;36(2):e23-8. https://doi.org/10.2500/aap.2015.36.3816 PMid:25715235

18. Elbehidy RM, Amr GE, Radwan HM. High sensitivity-C reactive protein as a novel marker for airway inflammation and steroid responsiveness in asthmatic children. Egypt $\mathrm{J}$ Bronchol. 2010;4:79-87.
19. Hadinedoushan H, Halvani A, Abdollahi E. The effects of inhaled Fluticasone on inflammatory markers in asthmatic patients. Basic Res J Med Clin Sci. 2014;3(5):39-44.

20. Sivapalan P, Bikov A, Jensen JU. Using blood eosinophil count as a biomarker to guide corticosteroid treatment for chronic obstructive pulmonary disease. Diagnostics. 2021;11(2):236. https://doi.org/10.3390/diagnostics 11020236

PMid:33546498

21. Nathan RA, Sorkness CA, Kosinski M, Schatz M, Li JT, Marcus $P$, et al. Development of the asthma control test: A survey for assessing asthma control. J Allergy Clin Immunol. 2004;113(1):59-65. https://doi.org/10.1016/j.jaci.2003.09.008 PMid: 14713908

22. Rogala B, Majak P, Glück J, Dębowski T. Asthma control in adult patients treated with a combination of inhaled corticosteroids and longacting 32 agonists: A prospective observational study. Pol Arch Intern Med. 2017;127(2):100-6. https://doi.org/10.20452/ pamw.3899 PMid:28220767

23. Schmidt O, Petro W, Hoheisel G, Kanniess F, Oepen P, LangerBrauburger B. Real-life effectiveness of asthma treatment with a fixed-dose fluticasone/formoterol pressurised metered-dose inhaler-results from a non-interventional study. Respir Med. 2017;131:166-74. https://doi.org/10.1016/j.rmed.2017.08.017 PMid:28947024 